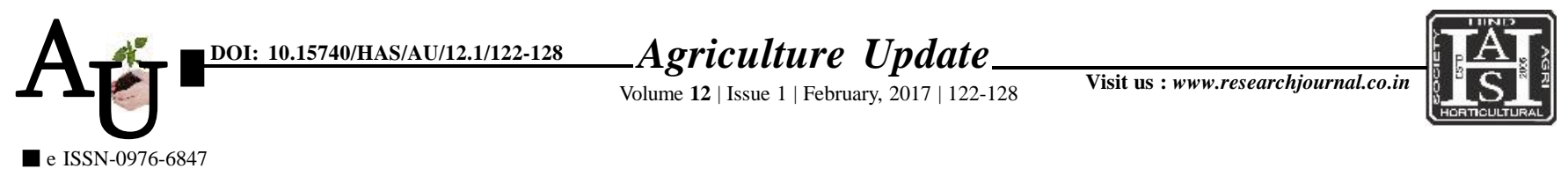

\title{
Rевевсн автісі: Adoption of recommended interventions of wheat among the respondents of RKVY
}

\author{
SUNITA KUMARI AND F.L. SHARMA
}

Article Chronicle: Received : 15.12.2016;

Revised : 07.01.2017;

Accepted :

14.01.2017

SUMMARY : The present study was conducted in which two tribal (Jhadol and Sarada) and two nontribal (Bhinder and Mavli) panchayat samities of Udaipur district of Rajasthan. Four beneficiary villages and two non-beneficiary villages from each selected panchayat samiti were taken and 10 respondents were selected randomly from each selected village for the study. Data were collected through prestructured interview schedule. The findings revealed that majority of beneficiary and non-beneficiary farmers belonged to medium adoption group. It was found that there was a significant difference in level of adoption between beneficiary and non-beneficiary farmers about recommended wheat interventions.

How to cite this article : Kumari, Sunita and Sharma, F.L. (2017). Adoption of recommended interventions of wheat among the respondents of RKVY. Agric. Update, 12(1): 122-128; DOI : 10.15740/HAS/AU/12.1/122-128.

KEY WoRds :

Adoption, interventions, Demonstration, Seed minikits, Beneficiary respondents, Nonbeneficiary respondents, RKVY

Author for correspondence :

SUNITA KUMARI

Department of

Extension Education,

Rajasthan College of

Agriculture, Maharana

Pratap University of

Agricultural University,

UDAIPUR (RAJASTHAN)

INDIA

Email:sunitaladsar

@ gmail.com

See end of the article for

authors' affiliations 